\title{
A ambivalência do riso em Rousseau e Diderot
}

\author{
Franklin de Mattos
}

Universidade de São Paulo 

Segundo o Livro VII das Confissões ${ }^{1}$, em fins de 1747, Rousseau, Diderot e d'Alembert quase fundaram um periódico que deveria chamar-se Le Persifleur, e cuja finalidade era submeter à crítica os livros novos, num tom humorístico, à maneira inglesa. No programa que esboçou para o jornal, Jean-Jacques começou por zombar de si próprio: "Ninguém é tão diferente de mim quanto eu mesmo. (...) Às vezes sou um duro e feroz misantropo, em outros momentos entro em êxtase em meio aos charmes da sociedade e às delícias do amor. Ora sou austero e devoto, (...) mas me torno logo um franco libertino. (...) Numa palavra, um Proteu, um camaleão, uma mulher são seres menos mutáveis do que eu". (Apud. Raymond, 2003, pp. 201-2)

Raymond Trousson observa que esses gracejos são mais próprios de Diderot do que de Rousseau. Diante deles, quem não se lembra dos reparos que o autor dos Salões fará ao seu retrato por Van Loo: "Eu tinha num dia cem fisionomias diversas"?. Quem não se recorda da comparação entre sua cabeça de Langrois, jamais fixa num ponto qualquer, e um galo de campanário, girando ao sabor dos ventos?. Para Trousson, aqui Rousseau se extenua em perseguir o "tom", o "ritmo" e o "espírito" de Diderot. Não que se pareça com ele, mas deseja parecer-se. (Numa nota de rodapé no princípio do Livro IX das mesmas Confissões, Rousseau diz: "não sei como todas as minhas conversações com ele [Diderot] tendiam sempre a me tornar satírico e mordaz, mais do que minha natureza me levava a sê-lo. Foi isto mesmo que me desviou de consultá-lo sobre um empreendimento [as primeiras redações do Contrato Social] no qual eu queria colocar unicamente toda a força do raciocínio, sem nenhum vestígio de humor e de parcialidade" (Rousseau, 1968, IX, p. 159). Voltaremos a essa espécie de oposição entre "o humor" e "a força do raciocínio", que torna 
incompatível com o riso a obra que veio a fundar o moderno republicanismo francês. $)^{2}$

Aproximadamente dez anos depois, em 1758, quando surgem a Carta a d'Alembert sobre os espetáculos, de Rousseau, e o Discurso sobre a poesia dramática, de Diderot, Jean-Jacques já não corre no encalço dele. De repente, os três amigos se surpreendem em campos diversos. Em nome do "progresso das artes" e dos "bons costumes”, Diderot e d'Alembert, diretores da Encyclopédie, são favoráveis à introdução do teatro em Genebra. Rousseau há muito não acredita que esses termos sejam solidários e, por isso, pronuncia-se contra. Com efeito, a Carta a d'Alembert desconstrói a ideia de teatro moral e, para tanto, escolhe como alvo privilegiado aquele que muitos consideram o mais moral dos gêneros dramáticos: a comédia. Numa inconfundível retórica, cheia de paradoxos, que tanto escandaliza e encanta seus adversários, Rousseau escreve:

Felizmente, a tragédia tal como existe está tão longe de nós, apresenta-nos seres tão gigantescos, tão empolados, tão quiméricos, que o exemplo de seus vícios não é muito mais contagioso do que é útil o de suas virtudes, e quanto menos ela quer nos instruir, menos mal nos faz também. Mas o mesmo não se passa com a comédia, cujos costumes têm com os nossos uma relação mais imediata, e cujos personagens se parecem mais com os homens. Tudo nela é mau e pernicioso, tudo tem graves consequências para os espectadores; e estando o próprio prazer do cômico baseado num vício do coração humano, segue-se desse princípio que quanto mais a comédia é agradável e perfeita, mais funesto para os costumes é o seu efeito (Rousseau, 1967, p. 92).

Em contrapartida, no Discurso sobre a poesia dramática, Diderot celebra o teatro cômico em todas as suas modalidades³, especial-

2 Sobre o republicanismo do Contrato social, ver Bignotto, 2010, p. 86-211.

3 Com a ressalva que será discutida adiante. 
mente o cômico sério, gênero em torno do qual gira sua reforma do espetáculo teatral. Para escolher exemplos tomados ao acaso:

Há três ordens de coisas. A história, onde o fato é dado; a tragédia, onde o poeta acrescenta à história aquilo que imagina aumentar-lhe o interesse; e a comédia, onde o poeta tudo inventa. Donde se pode concluir que o poeta cômico é o poeta por excelência. É ele quem tudo faz. É, em sua esfera, aquilo que o Ser todo-poderoso é na natureza. É ele quem cria, quem tira do nada (Diderot, 2005, p. 61)

\section{Ou então:}

Para o poeta dramático, os deveres dos homens constituem um filão tão rico quanto seus vícios e ridículos. As peças honestas e sérias sempre terão êxito, mas decerto principalmente entre povos corrompidos do que em outra parte. Indo ao teatro, poderão safar-se da companhia dos perversos que os cercam; é lá que encontrarão aqueles com quem gostariam de viver; é lá que verão a espécie humana tal qual é, reconciliando-se com ela (Id., ibid., p. 41).

Para Diderot, a moral (a saber, os deveres dos homens) é não apenas o objeto do gênero sério como seu efeito, que consiste na reconciliação entre o indivíduo e a natureza humana, essencialmente boa.

De um lado, aquele que pode transformar em maus os bons costumes; de outro, o criador que tudo inventa e nos reconcilia com a espécie - de que distintas concepções do riso dependem estas imagens tão díspares do poeta cômico?

Comecemos por refazer os principais argumentos da Carta a d'Alembert contra o gênero cômico.

A poética do teatro pretende que a comédia, ao ridicularizar os vícios, ensina a detestá-los. É o que disse Molière no famoso prefácio d'O Tartufo, no qual faz a defesa da comédia em geral e de sua peça: 
Os mais belos traços de uma séria moral são, com mais frequência, menos poderosos que os da sátira; e nada repreende melhor a maioria dos homens do que a pintura de seus defeitos. Expor os vícios às risadas de todo o mundo representa um grande golpe para eles. Toleram-se facilmente as repreensões, mas não se tolera a zombaria. A gente aceita ser malvado, mas não aceita ser ridículo" (Molière, 1965, p. 260).

É claro que Rousseau não ignora o poder do riso, ele que escreveu nas Confissões: "O que custa mais a dizer não é o crime, é o ridículo e o vergonhoso". (1959, I, p. 30). No entanto, embora aceite a premissa de Molière, Rousseau chega à conclusão oposta. Ao zombar dos vícios, a comédia não os torna odiosos, mas ridículos e, portanto, sua utilidade é levar o espectador a temer apenas os ridículos. Em outros termos, será que Rousseau sustenta que o poeta cômico torna, por assim dizer, aparentemente inofensivo aquilo que é odioso ${ }^{4}$ ? De todo modo, segundo ele, não se podem "curar" os ridículos sem "fomentar" os próprios vícios. Por que é esta “oposição necessária”? Mais ainda: por que o ridículo "é a arma favorita do vício”? E por que, um pouco adiante, Rousseau dirá que "o próprio prazer do cômico" está "fundado num vício do coração humano"?

Convém primeiro distinguir os termos: na Carta a d'Alembert, Rousseau fala em "comédia”, "ridículo”, “cômico” e "prazer do cômico”. O primeiro termo obviamente remete ao gênero dramático que, segundo Aristóteles, "imita” os homens "piores" do que são; os dois seguintes são sinônimos5 e em geral querem dizer "o

4 Talvez Rousseau esteja reinterpretando a seu modo a célebre definição de Aristóteles, retomada por Cícero e tantos outros. Diz a Poética: "A comédia é, como dissemos, imitação de homens inferiores; não, todavia, quanto a toda espécie de vícios, mas só quanto àquela parte do torpe que é o ridículo. O ridículo é apenas certo defeito, torpeza anódina e inocente” (Aristóteles, 1966, pág. 73). Para Rousseau-Alceste poderia haver "torpeza anódina e inocente"?

5 "Nos textos antigos, os termos que equivalem ao que chamo aqui de 'risível' são geloion, em grego, e ridiculum, em latim. Segundo Wilhelm Süss (1969), ambos designam o que, em alemão, é expresso por duas palavras: Komik e Witz - ou seja, aquilo que se entende por cômico em geral. O termo grego e, especialmente, o latino são 
objeto do qual se ri"; o último significa o prazer que este gera, o "riso" (ao contrário de Thomas Hobbes, por exemplo, Rousseau não costuma usar o vocábulo, ao menos na Carta). Além disso, a meu ver, na passagem acima, "ridículo" é empregado no sentido de "tornar ridículo", "ridicularizar”. É bom lembrar também que, para Rousseau, é cômico tudo aquilo que transgride as normas de certo grupo social - no caso de Molière, por exemplo, os defeitos que contrariam o gosto do homem mundano.

Disto isto, creio que, ao afirmar que o riso é um "vício do coração", Rousseau esteja reiterando, à luz de sua própria filosofia, a concepção hobbesiana segundo a qual rimos do outro para nossa própria glória e para dominá-lo. Com efeito, a paixão do riso anestesia nossa sensibilidade, excluindo qualquer outro sentimento; em última instância, é estranha à identificação e, portanto, à piedade, ${ }^{7}$ que, segundo Rousseau, é o fundamento derradeiro de todas as nossas virtudes; e, por fim, desperta em nós um sentimento de superioridade, lisonjeando nosso amor-próprio, que está na raiz das paixões humanas mais odientas e irascíveis.

Se assim for, não é difícil compreender as demais afirmações da Carta a d'Alembert. Se riso e virtude são incompatíveis para Rousseau, o ato de ridicularizar é a ferramenta preferida do vício, pois, por intermédio dele, excluímos e ao mesmo tempo domina-

algumas vezes traduzidos por 'ridículo'. Convém precisar contudo que, nestes casos, 'ridículo’ não tem necessariamente conotação negativa, remetendo antes àquilo de que se ri. R. Dupont-Roc e J. Lallot, em suas notas de leitura à Poética de Aristóteles, observam a propósito do termo geloion: 'o adjetivo geloios [...] pode equivaler ao francês 'ridicule', mas, substantivado, designa tecnicamente 'o cômico”' (Alberti, 1999, p. 39-40).

6 Verena Alberti inventariou os vários significados do vocábulo "ridículo" nos séculos XVII e XVIII. Ele pode designar "aquilo de que se ri", pode ser sinônimo de "erro", "vício" ou "desvio" e, afinal, pode significar o "ato de ridicularizar", que é bem o caso aqui. E prossegue lembrando que a Enciclopédia abre, significativamente, duas entradas para o termo: uma, conectada com o domínio da "poética”, refere-se "àquilo de que se ri na comédia"; a outra, que pertence ao mundo da "moral", considera-o ao mesmo tempo como "objeto ridicularizado" e "ato de ridicularizar" (Id., ibid., p. 121-2).

7 Este argumento será explicitado por Jean-Sébastien Mercier. "Mercier não diz outra coisa afirmando que o riso, 'convulsão maquinal', favorece a 'malícia natural do homem', enquanto a 'piedade' faz 'sua alma derramar-se”' (Richardot, 2002, pp. 242-3). 
mos o outro. A mesma incompatibilidade explica ainda por que o poeta cômico "cura" os ridículos "fomentando" os vícios: a comédia, por definição, não está comprometida com a virtude, mas com a "moral mundana"; portanto, não tem em vista os vícios, mas os ridículos, que, como se sabe, só podem ser evitados de modo vicioso.

Assim, o autor da Carta condena energicamente a concepção clássica do riso em suas vertentes mais fundamentais: a herança do ridículo, entendido como transgressão da norma - que vai de Platão aos séculos XVII e XVIII, e o legado da superioridade - de Quintiliano a Hobbes. Pelo último aspecto, lisonjeia nosso amor-próprio; pelo outro, seu grande efeito é nos submeter à "opinião", como se sabe, para Rousseau o maior dos males. A exemplo de Hobbes, Rousseau traz assim o fenômeno do riso para o coração de sua antropologia, procurando pensá-lo de maneira social e quiçá política.

Certamente a primeira tentação é confinar Diderot, sem mais, no interior da tradição clássica, cujo núcleo transparece no texto de Molière há pouco analisado. Com efeito, seus escritos costumam fazer a apologia da comédia jocosa, das comédias greco-latinas e do próprio teatro de Molière. Para escolher novamente um exemplo mais ou menos ao acaso, leia-se a seguinte passagem do Discurso sobre a poesia dramática:

Molière é muitas vezes inimitável. Tem cenas monossilábicas entre quatro ou cinco interlocutores, nas quais cada um deles diz apenas o que the cabe. Mas essa palavra pertence ao caráter, traça-lhe a figura. Há passagens n'As Sabichonas, que nos arrebatam a pluma das mãos. Se possuímos algum talento, ele se eclipsa. Permanecemos dias inteiros desgostosos e sem nada fazer. A coragem só reaparece à medida que esquecemos aquilo que havíamos lido e dissipa-se a impressão que havíamos sentido. (Diderot, 2005, p. 102)

Apesar da severa leitura que faz de Molière na Carta a d'Alembert, nem o próprio Rousseau jamais negaria seu gênio incomparável. Suas diferenças com Diderot são de outra ordem e 
ficam visíveis em algumas passagens do Discurso. Por exemplo:

O que é Aristófanes? Um farsista original. Um autor desse tipo deve ser precioso para o governo capaz de empregá-lo. A ele se devem entregar todos os entusiastas que volta e meia perturbam a sociedade. Expostos na feira, não encherão as prisões" (Id., ibid., p. 52).

O fragmento é bem claro: afirma a utilidade do poeta cômico, para os governos e as sociedades, integrando-o, além disso, ao combate das Luzes contra o fanatismo. Pouco importa que Diderot insista aqui na eficácia política, e não propriamente moral, da comédia. Sua premissa é a mesma da tradição clássica: ao ridicularizar os vícios, a comédia os previne, tornando-os inócuos.

Entretanto, nem sempre Diderot é, por assim dizer, tão ortodoxo... No Discurso, apresenta-se como o dramaturgo empenhado em promover a virtude e perseguir o vício, dirigindo-se ao grande público do tempo. Conforme já se notou, porém, outras vezes volta-se para leitores mais seletos ou até mesmo aposta na posteridade $^{8}$, como é o caso de O Sobrinho de Rameau, publicado alguns anos depois de sua morte. Nesses momentos, Diderot experimenta intensamente, testando ideias que muitas vezes ultrapassam os limites da Ilustração. Para a questão que nos interessa, basta lembrar a famosa tirada de Rameau, a propósito de Molière e La Bruyère:

Quanto a mim, aí recolho tudo o que se deve fazer, e tudo o que não se deve dizer. Assim, quando leio o Avaro, digo-me: Sê avaro, se quiseres; mas cuida de não falar como o avaro. Quando leio o Tartufo, digo-me: Sê hipócrita, se quiseres; mas não fales como o hipócrita. Conserva os vícios que te são úteis, mas não tenhas nem o tom nem a aparência que te tornariam

8 Este público mais restrito é o da Correspondência Literária, Filosófica e Crítica, periódico manuscrito dirigido sucessivamente por Raynal, Grimm e Meister, mantido por uma dúzia de príncipes e aristocratas estrangeiros e no qual Diderot publicou várias obras. A tese de que confiou vários escritos ao leitor futuro é de Herbert Dieckmann (Dieckmann, 1959). 
ridículo. Para se garantir desse tom, dessas aparências, é preciso conhecê-los. Ora esses autores fizeram deles excelentes pinturas. Eu sou eu e permaneço o que sou; mas ajo e falo como convém. (Diderot, 1977, p. 60).

É preciso desde logo observar que a primeira versão do Sobrinho data de 1760, quando as críticas da Carta a d'Alembert (1758) ainda estavam, por assim dizer, no ar. Em seguida, não se deve ignorar que o sujeito que fala já não é o dramaturgo da virtude, mas o parasita inescrupuloso e cínico. Será que devemos levar às últimas consequências o distanciamento a que Diderot nos convida? Não seria por uma calculada astúcia de dramaturgo que ele atribui as teses da Carta à d'Alembert à figura de Rameau justamente ao personagem que é o antifilósofo por excelência?

Posto isso, a passagem é claríssima: o poeta cômico já não é útil para o bom governo e a sociedade, mas parece feito de encomenda para o homem vicioso. O efeito da comédia já não é combater o vício mediante o ridículo, mas ensinar um sutil jogo de aparências, no qual o vicioso permanece aquilo que é, agindo e falando "como convém". A seu modo, Diderot retoma o argumento de Rousseau: a comédia ensina a evitar o ridículo, mas não o próprio vício. Será que Diderot, a exemplo do cidadão de Genebra, sustenta que a comédia é um gênero descomprometido com a virtude, que apenas promove a "moral mundana" e não tem em mira os vícios, mas os ridículos? Acho que deve ser testada a hipótese segundo a qual essa passagem deixa à vista a "desconfiança republicana" (a expressão é de Anne Richardot) em relação ao riso e à comédia, própria de uma parte das Luzes, de Rousseau, "e mais claramente ainda” de Diderot. ${ }^{9}$ Com efeito, continua Richardot, no Discurso sobre a poesia dramática, "o processo estético se duplica num problema político" e então Diderot assimila o cômico a usos aristocráticos, isto é, monárquicos. Por isso, afirma numa

9 Ver Richardot, 2002, p. 244-5. 
fórmula célebre: "Um povo não tem a mesma capacidade para se destacar em todos os gêneros de drama. A tragédia me parece mais adequada ao gênio republicano e a comédia, principalmente, a jocosa, ao caráter monárquico" (Diderot, 2005, p.106).

Inútil lembrar que também para Rousseau o fenômeno do riso não é algo simples e não deve ser reduzido à sua faceta cômica. Pode-se dizer que, segundo ele, cada povo ri à sua maneira. Mistificador e "méchant" é o riso que se ouve em Paris, nos teatros, nos salões e até nas ruas. No campo, tudo é diferente. Basta referir a recordação de infância que fecha a Carta a d'Alembert e que relata a festa improvisada do regimento genebrino de Saint-Gervais.

Lembro-me de ter sido tocado na infância por um espetáculo muito simples, cuja impressão, porém, sempre me ficou, apesar do tempo e da diversidade dos objetos. O regimento de Saint-Gervais havia feito o exercício e, como de hábito, haviam ceado por companhias; a maior parte daqueles que as compunham reuniram-se depois da ceia na praça de Saint-Gervais e se puseram a dançar todos juntos, oficiais e soldados, ao redor da fonte, sobre a bacia da qual haviam subido os tambores, os pífaros e aqueles que carregavam as tochas. (...) Era tarde, as mulheres estavam deitadas, todas se levantaram. Logo as janelas ficaram cheias de espectadoras que davam um novo ânimo aos atores; elas não aguentaram ficar muito tempo às janelas e desceram; as esposas vinham ver os maridos, as criadas traziam vinho, as próprias crianças, acordadas pelo barulho, acorreram semivestidas entre os pais e as mães. A dança foi suspensa; tudo foi beijos, risos, brindes, carícias. Disso tudo resultou um enternecimento geral que eu não seria capaz de retratar, mas que, na alegria universal, sentimos muito naturalmente em meio a tudo que nos é caro. Meu pai, ao abraçar-me, foi tomado de um tremor que ainda creio sentir e compartilhar. (Rousseau, 1967, p. 248) 
Jean Starobinski (1987, p. 116ss) chamou essa festa de "norma interior" que serve para julgar os espetáculos na Carta à d'Alembert. Como bem mostra, contribuem para o "enternecimento geral" (a expressão é de Jean-Jacques) o repasto, o vinho, a música, os uniformes, a temporária igualdade entre amos e servidores. Escapou-lhe, porém, a discreta e reveladora presença do riso, que Anne Richardot (2002, p. 202ss), por sua vez, trouxe ao primeiro plano: "La danse fut suspendue: ce ne fut qu'embrassements, ris, santés, caresses”. Segundo Richardot, para além do contexto de reflexão política no qual se insere, este texto mobiliza uma rede de significações sobre a "alegria coletiva e a comunicação entre os seres que ela encoraja". Cada qual é ao mesmo tempo "receptor" e "emissor" não apenas daquilo que Rousseau chama de "enternecimento geral", mas também do que qualifica de "alegria universal".

Nenhuma barreira entrava a participação de todos neste regozijo: as mulheres, a princípio às janelas, como num camarote de teatro, logo descem para misturar-se à multidão reunida. Os oficiais e os simples soldados dançam 'todos juntos', o pai tremendo de alegria beija o filho. Todos permanecem até tarde da noite, 'a rir e a conversar', hesitando em separar-se, em desatar esses laços tecidos pelo riso. Recordação antiga, mas entalhe profundo na memória, essa noite se põe como modelo. A partir desse esquema vai edificar-se o imaginário rousseauísta da festa ideal, e de seu contrário". (Id., ibid., p. 203)

Por isso, alguns estudiosos ${ }^{10}$ insistiram que, para Rousseau, têm efeitos políticos opostos o teatro clássico francês e a festa improvisada: enquanto o primeiro separa os homens, a segunda os reúne. Do mesmo modo, pode-se afirmar que, para o autor da Carta e da Nouvelle Heloïse, o riso mundano exclui e aparta, enquanto o riso feliz junta e agrega. Com efeito, não é o primeiro 
um riso aristocrático, de classe, ao passo que o segundo cria laços, por assim dizer, republicanos, reforçando, como diria Montesquieu, o amor da pátria e da igualdade?

Comecei por uma anedota que atestava a cumplicidade entre Diderot e Rousseau, termino por outra, que anuncia seu fim. Ela se passou no começo de 1754, poucos anos antes da Carta a d'Alembert e do Discurso sobre a Poesia Dramática, e revela duas coisas: em primeiro lugar, a vocação de Diderot para a comédia e a farsa e, em seguida, a aversão de Rousseau pelo riso maligno, o que ajuda a explicar seu crescente mal-estar entre os enciclopedistas. Para que se tenha uma ideia do quanto é emblemática, basta lembrar que deve ter se passado numa das últimas visitas de Rousseau à "coterie holbachique" (maneira pela qual As Confissões se referem ao salão do barão d'Holbach). O episódio mostra ainda que a aversão de Jean-Jacques pelo riso maligno não era apenas de ordem livresca.

Para bem saboreá-la, é preciso dizer que, em meados do século XVIII, torna-se cada vez mais comum na boa sociedade um jogo a que as Luzes deram o nome de "mistificação" (não por acaso título de um conto de Diderot). De acordo com Jean Catrysse, menos agressiva que a “zombaria”, “'a mistificação’ não passaria de um embuste divertido, um jogo gratuito, visando apenas à finalidade de divertir e fazer rir" (Catrysse, 1970, p. 24). Lise Andries, por sua vez, afirma que, “segundo Les Mémoires secrets de Bachaumont, 'deve-se entender pela palavra mistificação as armadilhas nas quais se faz cair um homem simples e crédulo, e que servem para zombar dele" (Andrie, 2000, p.14.)

No verão de 1753, durante um passeio no jardim de Luxembourg, Diderot, que já se tornara escritor de renome, travou conhecimento com um jovem clérigo de aldeia, o padre Petit, que lhe submeteu à queima-roupa, para sua apreciação, os setecentos 
versos de um enorme madrigal. Diderot certamente empalideceu e para safar-se alegou que só ouviria os versos do poeta quando ele compusesse algo num gênero maior - uma tragédia, por exemplo. Meses depois, voltou o importuno, empunhando a peça "encomendada", que, a título de antepasto, vinha precedida de uma espécie de poética do teatro, cheia dos maiores disparates. Obrigado pela palavra empenhada, mas decerto para tornar tamanha refeição menos indigesta, Diderot marcou uma leitura pública no salão do barão d'Holbach e, no dia combinado, lá estava o pobre diabo, diante da nata do enciclopedismo, que o ouvia, ora gravemente, ora de modo zombeteiro. Jean-Jacques era o único calado e imóvel, afundado numa poltrona, mas, de repente, levantou-se com ímpeto, arrancou o manuscrito das mãos do autor e disse: Sua peça e seu discurso não valem nada, não vê que todos estão caçoando do senhor? Saia daqui e volte para sua paróquia! O padre também se pôs furioso, cobriu Rousseau dos maiores impropérios e com certeza teria chegado às vias de fato, não fosse contido pelos demais. D'Holbach, a quem devemos o relato desse episódio - que principia, no estilo de Diderot, num registro cômico, e termina, à Rousseau, de modo dramático - conclui: "Rousseau saiu tomado de uma raiva que acreditei momentânea, mas que não se acabou e que só fez mesmo crescer desde então" (Apud Wilson, 1985, p. 154).

Não custa repetir: impossível anedota mais emblemática! Em primeiro lugar, surpreende quase in statu nascendi um jogo cada vez mais comum a partir dos anos 50 e situa Diderot e Rousseau diante dele. Os componentes da definição de Bachaumont aparecem de modo mais transparente: de um lado, "um homem simples e crédulo", um padre (e, para o cúmulo, de nome Petit!), imagina-se no limiar da glória, mas na verdade cai na armadilha da zombaria; de outro, o "riso coletivo", que se exerce às custas daquele que o grupo exclui. É uma cena de comédia clássica, improvisada pelo talento de Diderot. O pobre Petit não apenas está convencido de que seus versos têm valor, como ainda pretende ter 
algo a dizer - a Diderot e seus amigos! - sobre a poética do teatro. Em suma, almeja ao reconhecimento daquilo que muitos chamam de "Igreja de Voltaire"! Quem é ele senão uma das figuras mais ridicularizadas pelos poetas cômicos de todos os tempos, o personagem picado pelo vício da vanglória?

Porém, acaba faltando à encenação de Diderot o espectador edificado, que aprende afinal a reconhecer seu justo lugar no mundo. Em vez dele quem aparece é o seu antagonista, para quem o riso não corrige ninguém e que sobe ao palco para interromper a cena e recusar a peça.

\section{Referências bibliográficas}

ALBERTI, V. O Riso e o Risível na História do Pensamento. Rio de Janeiro: Jorge Zahar Editor, 1999.

ANDRIE, L. "Présentation", in Dix-Huitiéme Siècle. Paris : PUF, 2000.

ARISTÓTELES, Poética. Trad. Eudoro de Sousa. Porto Alegre: Ed. Globo, 1966.

BIGNOTO, N. As aventuras da virtude. São Paulo: Companhia das Letras, 2010.

CATRYSSE, J. Diderot et la mystification,.Paris: Nizet, 1970.

DIDEROT, D. Discurso sobre a poesia dramática. Trad. Franklin de Mattos. São Paulo: Cosac \& Naify, 2005. . Le Neveu de Rameau. Genebra: Droz, 1977,

DIECKMANN, H. "Diderot et son lecteur", in Cinq leçons sur Diderot. Genève-Paris: Librairie Droz-Minard, 1959).

MOLIÈRE, J. "Préface" a "Le Tartuffe ou l'Imposteur", in Oeuvres Complètes II. Paris: Garnier-Flammarion, 1965

PRADO Jr, B. A retórica de Rousseau. São Paulo, CosacNaify, 2008, RICHARDOT, A. Le rire des Lumières. Paris: Honoré Champion 
Editeur, 2002.

ROUSSEAU, J. J. As Confissões. Trad. Rachel de Queiroz. São Paulo: Atena Editora, 1959. . Les Confessions. In: Oeuvres Complètes II. Paris: Garnier-Flammarion, 1968. . Lettre a d'Alembert sur les spectacles. In: Oeuvres Complètes IV. Paris: Garnier-Flammarion, 1967.

STAROBINSKI, J. Jean-Jacques Rousseau - La transparence et l'obstacle. Paris: Gallimard, 1972.

TROUSSON, R. Jean-Jacques Rousseau. Paris: Editions Tallandier, 2003 .

WILSON, A. M. Diderot - Sa vie et son oeuvre. Paris: LafontRamsey, 1985. 